\title{
Actions of second messengers synthesized by various spasmogenic agents and their relation to mechanical responses in dog tracheal smooth muscle
}

\author{
Hideaki Katsuyama, *Satoshi Suzuki \& *Eiichiro Nishiye
}

Second Department of Oral Surgery, Faculty of Dentistry, and *Department of Pharmacology, Faculty of Medicine, Kyushu University, Fukuoka 812, Japan

1 The effects of the spasmogenic agents, carbachol (CCh), histamine, 5-hydroxytryptamine (5-HT) and 9,11-epithio-11,12-methano-thromboxane $\mathrm{A}_{2}\left(\mathrm{STA}_{2}\right)$ were investigated on smooth muscle tissues of the dog trachea.

$2 \mathrm{CCh}(10 \mu \mathrm{M})$ produced a larger contraction than high $\mathrm{K}(128 \mathrm{mM}), 10 \mu \mathrm{M}$ histamine, 5-HT or STA 2 . Histamine and 5-HT produced the same amplitude of contraction as each other. In Ca-free solution containing $0.2 \mathrm{~mm}$ EGTA, only a phasic contraction was evoked by the above agents (except for $\mathrm{K}$ which induced no contraction at all).

3 In skinned muscle tissues, the maximum amplitude of contraction that could be induced by $\mathrm{Ca}(10 \mu \mathrm{M})$ was slightly larger than the maximum $\mathrm{CCh}$-induced contraction (also at $10 \mu \mathrm{M}$ ) evoked in intact muscle tissues. Caffeine and inositol 1,4,5-trisphosphate $\left(\mathrm{IP}_{3}\right)$ both produced contraction.

$4 \mathrm{CCh}$, histamine and 5-HT $(10 \mu \mathrm{M})$ produced a sustained contraction for over $30 \mathrm{~min}$ and also increased phosphorylation of the $20 \mathrm{kD}$ protein of myosin light chain $\left(\mathrm{MLC}_{20}\right)$ for over $30 \mathrm{~min}$ with no attenuation. Greater concentrations of the above agents caused more phosphorylation of $\mathrm{MLC}_{20}$.

$5 \mathrm{CCh}$ (above $1 \mathrm{nM}$ ), histamine (above $10 \mathrm{nM}$ ) and 5-HT (above $100 \mathrm{nM}$ ) increased the amount of $\mathrm{IP}_{3}$, in a concentration-dependent manner. Synthesis of $\mathrm{IP}_{3}$ induced by the above agents reached its peak value within $30 \mathrm{~s}$ and lasted for about $3 \mathrm{~min}$. The potencies for the synthesis of $\mathrm{IP}_{3}$ were in the following order: $\mathrm{CCh}>$ histamine $>5-\mathrm{HT}>\mathrm{STA}_{2}$.

6 Isoprenaline $(10 \mu \mathrm{M})$ markedly enhanced but $\mathrm{CCh}(10 \mu \mathrm{M})$ slightly reduced the amount of cyclic AMP. 5-HT $(10 \mu \mathrm{M})$ and STA $2(10 \mu \mathrm{M})$ reduced, but histamine $(10 \mu \mathrm{M})$ and CCh $(10 \mu \mathrm{M})$ increased the amount of cyclic GMP.

7 Using fura 2, cytosolic Ca was measured by monitoring the ratio of the fluorescent signal excited at 340 and $380 \mathrm{~nm}$ wavelengths in the presence of extracellular Ca. CCh $(10 \mu \mathrm{M})$ increased the Ca transient from $182 \mathrm{nM}$ to $1.42 \mu \mathrm{M}$. When the CCh-induced peak Ca transient $(10 \mu \mathrm{M})$ was normalised, $10 \mu \mathrm{M}$ histamine, 5-HT and STA 2 showed smaller values such as $0.49,0.53$ and 0.04 times the control, respectively, and these values corresponded well with the amplitudes of contraction evoked by each of the stimulants.

8 The results can be summarized as follows: stronger spasmogenic responses occur on application of CCh than on application of 5-HT or histamine, and STA $\mathrm{S}_{2}$ may have a minor role as a spasmogenic agent. The maximum amplitudes (peaks) of contraction evoked by the above spasmogenic agents are closely related to the maximum increase in cytosolic $\mathrm{Ca}$, but sustained contraction and increased phosphorylation of myosin cannot be explained by the increased amount of $\mathrm{Ca}$. In the case of 5-HT and histamine, synthesized cyclic nucleotides may interact with the action of $\mathrm{IP}_{3}$ for the regulation of contraction in a positive or negative manner, respectively.

\section{Introduction}

Airway smooth muscle tissues show both regional and species differences in their responses to various spasmogenic agents. For example, in the rabbit airway, the potassium (128 mM K)and histamine $(10 \mu \mathrm{M})$-induced contractions in the trachea are much smaller than the acetylcholine (ACh, $10 \mu \mathrm{M}$ )-induced contraction, but in the third branch of the right middle bronchial tree, these same three stimulants generate much the same amplitude of contraction and, moreover, the amplitude of the ACh-induced contraction is larger than that observed in the trachea (Fujiwara et al., 1988). In the guinea-pig, dog, bovine and rabbit tracheal and bronchial tissues, histamine produces contraction by stimulation of the $\mathbf{H}_{1}$-receptor, though $\mathrm{H}_{2}$-receptors are also present (Chand \& Eyre, 1975; Kirkpatrick, 1975; Kotlikoff et al., 1987). Ito \& Tajima (1982) demonstrated that in the dog trachea, isoprenaline produces hyperpolarization of the membrane, reduces the resting tone and relaxes tissues precontracted by $\mathrm{ACh}$. However, in the bovine trachea, isoprenaline stimulates the $\beta_{2}$-adrenoceptor and increases $\mathrm{Ca}$ influx through activation of the receptoroperated (dihydropyridine- and pertussis toxin-sensitive) $\mathrm{Ca}$ channel, whereas isoprenaline reduces $\mathrm{Ca}$ influx following pretreatment with carbachol (CCh) (Felbel et al., 1988). Furthermore, the same authors showed that $\mathrm{CCh}$ increases the influx of $\mathrm{Ca}$ and releases $\mathrm{Ca}$ from the sarcoplasmic reticulum and also that the channel responsible for the accelerated influx of $\mathrm{Ca}$ is the same as that by which isoprenaline causes $\mathrm{Ca}$ influx. However, in the rabbit, cat and guinea-pig trachea the maximum amplitude of $\mathbf{K}$-induced contraction, i.e. when activation of the voltage-dependent dihydropyridine-sensitive $\mathrm{Ca}$ channel is maximum, is about $20 \%$ of the $\mathrm{CCh}$-induced contraction and in the rabbit trachea, Ca-channel blockers $(\mathrm{Ca}$ antagonists) inhibit the tonic response but not the phasic response of the contraction.

In the dog tracheal smooth muscle cell, ACh and 5hydroxytryptamine (5-HT) stimulate the production of myoinositol 1,4,5-trisphosphate $\left(\mathrm{IP}_{3}\right)$ in the soluble fraction (Hashimoto et al., 1985). Histamine increases the amount of adenosine 3': 5'-cyclic monophosphate (cyclic AMP) through stimulation of the $\mathrm{H}_{2}$-receptor (Beaven, 1978). In the bovine and guinea-pig tracheal smooth muscle tissues, histamine increases guanosine $3^{\prime}$ : 5'-cyclic monophosphate (cyclic GMP; Duncan et al., 1980; Nakagawa et al., 1986). This latter action 
is blocked by diphenhydramine, an $\mathrm{H}_{1}$-antagonist (Ganellin \& Parsons, 1982). It is therefore apparent that many second messengers, such as $\mathrm{Ca}$, cyclic nucleotides, $\mathrm{IP}_{3}$ and diacylglycerol may contribute to the generation of contraction induced by various stimulants.

The present experiments were intended to clarify the effects on dog tracheal smooth muscle tissues of the spasmogenic agents, CCh, histamine, 5-hydroxytryptamine (5-HT) and 9,11-epithio-11,12-methano-thromboxane $\mathrm{A}_{2}$ (STA $\mathrm{ST}_{2}$; a stable thromboxane $A_{2}$ analogue). To obtain parameters of muscle responses, measurements were made of the mechanical response, amounts of free $\mathrm{Ca}$, of cyclic nucleotides (cyclic AMP and cyclic GMP) and of $\mathrm{IP}_{3}$, and the phosphorylation of the $20 \mathrm{kD}$ protein of the myosin light chain.

\section{Methods}

\section{Materials}

Adult mongrel male dogs weighing $10-15 \mathrm{~kg}$ were anaesthetized with intravenous pentobarbitone $\left(10-30 \mathrm{mg} \mathrm{kg}^{-1}\right)$. Segments of the cervical trachea were excised and a dorsal strip of transversely running smooth muscle was separated from the cartilage. The mucosa and adventitial areolar tissues were carefully removed, under the microscope. The tracheal smooth muscle was cut into sections: (a) $0.05-0.08 \mathrm{~mm}$ in width and $0.3-0.4 \mathrm{~mm}$ in length for tension recording in intact and skinned muscle tissues and for measurements of $\mathrm{Ca}$ transients using fura 2 , and (b) $2 \mathrm{~mm}$ in width and $5-7 \mathrm{~mm}$ in length for the phosphorylation of the $20 \mathrm{kD}$ protein of the myosin light chain.

For measurements of cyclic nucleotides and $\mathrm{IP}_{3}$, dispersed smooth muscle cells were prepared with collagenase as described by Sumimoto \& Kuriyama (1986). The cell viability, as assessed by the trypan blue exclusion test, was over $85 \%$.

\section{Solutions}

The Krebs solution contained (mM): $\mathrm{Na}^{+} 137.5, \mathrm{~K}^{+} 5.9, \mathrm{Cl}^{-}$ 134.4, $\mathrm{Mg}^{2+} 1.2, \mathrm{Ca}^{2+} 2.6, \mathrm{HCO}_{3}^{-} 15.5, \mathrm{H}_{2} \mathrm{PO}_{4}^{-} 1.2$ and glucose 11.5. It was of pH 7.3 and was bubbled with $97 \% \mathrm{O}_{2}$ and $3 \% \mathrm{CO}_{2}$. High $\mathrm{K}$-solution was prepared by replacing $\mathrm{NaCl}$ with equimolar $\mathrm{KCl}(128 \mathrm{~mm} \mathrm{~K})$. Ca-free solution was prepared by substituting $\mathrm{MgCl}_{2}$ for $\mathrm{CaCl}_{2}$ in the $\mathrm{Krebs}$ solution and adding $0.2 \mathrm{mM}$ EGTA. For the experiments on skinned muscle strips, the following solutions were used (mM): K-methanesulphonate (KMs) $110, \mathrm{Mg}(\mathrm{Ms})_{2} \quad 5, \mathrm{Na}_{2} \mathrm{ATP}$, ethyleneglycol-bis- $\left(\beta\right.$-aminoethyl ether)-N,N, $N^{\prime}, N^{\prime}$-tetraacetic acid (EGTA) 4, piperazine- $\mathrm{N}$ - $\mathrm{N}^{\prime}$-bis-(2-ethanesulphonic acid)(PIPES) 20; the pH being adjusted to 6.8 with $\mathrm{KOH}$ at $25^{\circ} \mathrm{C}$. Solutions of desired $\mathrm{Ca}$ concentration were prepared by adding appropriate amounts of $\mathrm{Ca}$ to the relaxing solution. The precise methods for calculating free ionic concentrations and the binding constants used have been described by Fujiwara et al. (1989).

\section{Tension recordings from intact and skinned muscle strips}

Mechanical responses were measured by attaching smooth muscle strips prepared from the trachea to a strain gauge $(U-$ gauge, Shinko, Tokyo), as described previously (Fujiwara et al., 1989). Tension recordings were started after repetitively generated $\mathrm{K}$-induced contractions showed the same amplitude (about $2-4 \mathrm{~h}$ after placing the tissue in the bath) and spasmogenic agents were applied for $3 \mathrm{~min}$ at $10-15 \mathrm{~min}$ intervals. Responses were found to be reproducible with this procedure. Control responses, recorded before and after each trial, were also reproducible. Concentration-response relationships were obtained by application of various concentrations of spasmogens for $3 \mathrm{~min}$ at $15 \mathrm{~min}$ intervals.
Skinned tissues were prepared by use of saponin $\left(40 \mu \mathrm{g} \mathrm{ml}^{-1}\right.$, for $20 \mathrm{~min}$ ), as described previously (Itoh et al., 1986). To prevent deterioration of the Ca-sensitivity of the contractile proteins, $0.1 \mu \mathrm{M}$ calmodulin was present throughout the experiments. The tension-pCa relationship was obtained by cumulative application of solutions containing various $\mathrm{Ca}$ concentrations and buffered with $4 \mathrm{mM}$ EGTA (Itoh et al., 1986).

\section{Measurements of phosphorylation of $20 \mathrm{kD}$ protein of myosin light chain}

The muscle strips were stimulated with spasmogenic agents and were quickly frozen by acetone-dry ice. The strips were then homogenised in a solution containing $5 \%$ trichloroacetic acid (TCA) and were centrifuged at $12,000 \mathrm{~g}$ for $15 \mathrm{~min}$. The pellet was washed with the solution containing $2 \% \mathrm{TCA}$ and $5 \mathrm{mM} \mathrm{KH}_{2} \mathrm{PO}_{4}$ and centrifuged at $12,000 \mathrm{~g}$ for $15 \mathrm{~min}$ at $4^{\circ} \mathrm{C}$, dissolved in lysis buffer containing $0.25 \mathrm{M} \mathrm{Na} \mathrm{NPO}_{4}, 0.3 \%$ sodium dodecyl sulphate (SDS) and 5\% 2-mercapto-ethanol and then homogenised. Two-dimensional gel electrophoresis involving isoelectric focusing (IEF) in the first dimension and SDS electrophoresis in the second dimension, as developed by O'Farrell (1975), was used for the resolution of myosin light chain phosphorylation. The IEF gels $4 \%$ polyacrylamide $(1.0 \mathrm{~mm}$ in diameter and $110 \mathrm{~mm}$ in length) containing $8.5 \mathrm{M}$ urea, 2\% Nonidet P-40 (NP-40), and 2\% Pharmacia carrier

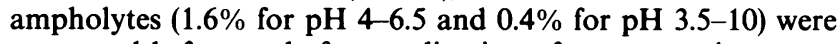
compared before and after application of spasmogenic agents. Lysis buffer containing $500 \mu \mathrm{g}$ of protein was applied and focused at a constant voltage of $200 \mathrm{~V}$ for $2 \mathrm{~h}, 440 \mathrm{~V}$ for $13 \mathrm{~h}$ and $800 \mathrm{~V}$ for $1 \mathrm{~h}$. After being focused, the gels were loaded onto the SDS electrophoresis unit. The SDS electrophoresis gels $(140 \mathrm{~mm}$ in width and $1.5 \mathrm{~mm}$ in thickness) comprised stacking gels $(50 \mathrm{~mm}$ in height with $4 \%$ polyacrylamide in $0.1 \%$ SDS and $0.125 \mathrm{M}$ Tris- $\mathrm{HCl}$ at $\mathrm{pH} 6.8$ ) and separating gels $(100 \mathrm{~mm}$ in height with $13.5 \%$ polyacrylamide in $0.1 \%$ SDS and $0.345 \mathrm{M}$ Tris- $\mathrm{HCl}$ at $\mathrm{pH} \mathrm{8.8).} \mathrm{The} \mathrm{gels} \mathrm{were} \mathrm{run} \mathrm{at} \mathrm{a}$ constant current density of $25 \mathrm{~mA}$ in the stacking gels and $40 \mathrm{~mA}$ in the separating gels. The gels were stained and fixed overnight with $0.25 \%$ Coomassie Brilliant Blue R-250, $45 \%$ ethanol, and $10 \%$ acetic acid, and then destained. The distribution of the stained protein $(20 \mathrm{kD}$ myosin light chain; $\mathrm{MLC}_{20}$ ) exhibited the first and second (and sometimes third) spots from higher to lower $\mathrm{pI}$ values. The intensity of these spots was measured with a chromatography densitometer equipped with an automatic integrator (CS-910, Shimazu, Kyoto). The first area and the second area at around pl 5.45 were meausured to obtain the relative value of $\mathrm{MLC}_{20}$ phosphorylation, which is expressed as a percentage, derived from a division of the second spot area by the sum of the first and second spot areas, as described by Driska et al. (1981).

\section{Measurements of cyclic nucleotides and $I P_{3}$}

Cell suspensions $\left(450 \mu \mathrm{l} ; 0.5 \times 10^{6} \mathrm{cells} \mathrm{ml}^{-1}\right)$ were incubated at $37^{\circ} \mathrm{C}$ for $30 \mathrm{~min}$, and $50 \mu \mathrm{l}$ of each agonist dissolved in Krebs solution was added. The reaction was terminated by adding $500 \mu \mathrm{l}$ ice cold $15 \%(\mathrm{w} / \mathrm{v})$ trichloroacetic acid. After homogenisation, proteins were sedimented by centrifugation at $3000 \mathrm{~g}$ for $15 \mathrm{~min}$ at $4^{\circ} \mathrm{C}$. Supernatants were separated and extracted three times with 3 volumes of $\mathrm{H}_{2} \mathrm{O}$-saturated diethyl ether and then titrated to $\mathrm{pH} 7.5$ with $\mathrm{NaHCO}_{3}$.

$\left[{ }^{3} \mathrm{H}\right]-\mathrm{IP}_{3},\left[{ }^{125} \mathrm{I}\right]$-cyclic AMP and $\left[{ }^{125} \mathrm{I}\right]$-cyclic GMP assay systems (Amersham TRK. 1000, RPA. 509 and RPA. 525, respectively) were used for the measurements of $\mathrm{IP}_{3}$, cyclic AMP and cyclic GMP, respectively. The protein concentration was determined by the method of Lowry et al. (1951).

\section{Measurements of Ca concentrations with fura 2}

Muscle strips $(0.3-0.5 \mathrm{~mm}$ long and $0.1 \mathrm{~mm}$ diameter) were loaded for $2 \mathrm{~h}$ in Krebs solution containing $5 \mu \mathrm{M}$ acetoxy- 
methyl ester (fura 2-AM) dissolved in dimethyl sulphoxide (DMSO) (premixed with cremophor EL; final concentration $0.02 \%)$, at room temperature $\left(25 \pm 1^{\circ} \mathrm{C}\right)$. The loaded muscle strips were fixed at both ends with 'Scotch' double-sided tape in a $1 \mathrm{ml}$ chamber, the bottom was covered with $24 \times 24 \mathrm{~mm}$ width and $0.13-0.17 \mathrm{~mm}$ thickness micro cover glass (Matsunami Glass IND. Ltd., Tokyo, Japan) and immersed in Krebs solution containing $2.6 \mathrm{~mm} \mathrm{Ca}$ at room temperature. The chamber was fixed on the stage of a microscope (DIAPHOTO-TMD, Nikon, Tokyo, Japan).

Experiments were performed with a fluorimeter (Spex Fluorolog-2 Spectrofluorometer, Spex Industries Inc., N.J. U.S.A.). The muscle strips were excited by light obtained from xenon high pressure lamp (1907 OFR, $450 \mathrm{~W}$ ) with power supplied by $1970 \mathrm{P}$ and the measured field was a round spot $250 \mu \mathrm{m}$ diameter in the middle portion of thin muscle strip. The slits at the entrance and exit ports of both the excitation and emission spectrophotometers were fixed at $2 \mathrm{~mm}$ and the bandpass was $3-4 \mathrm{~mm}$. Two alternative excitation wavelengths, $340 \mathrm{~nm}$ (F340) and $380 \mathrm{~nm}$ (F380), were used and the emission was monitored at $505 \mathrm{~nm}$. Both F340 and F380 were measured continuously and the ratio of F340/F380 was calculated.

The data were acquired and analysed on a DM 3000F Spectroscopy Computer (Spex, N.J., U.S.A.) with DM 3000 software. Determinations of absolute values of free $\mathrm{Ca}$ were difficult because of the difficulty in eliminating autofluorescence from the signal, the amount of fura 2-AM remaining (Luckhoff, 1986; Himpens \& Somlyo, 1988) and also the unknown value of the dissociation constant of the fura 2-Ca complex in smooth muscle cytoplasm (Sato et al., 1988). Therefore, in the present experiments absolute calibrations of the Ca transient (Grynkiewicz et al., 1985) were only performed at the end of experiments and the maximum (Fmax) and minimum (Fmin) fluorescences were obtained by use of $10 \mu \mathrm{M}$ ionomycin in Krebs and Ca-free solutions, respectively. An assumed dissociation constant of $224 \mathrm{~nm}$ (Tsien et al., 1985) was used for calculating the cytosolic free $\mathrm{Ca}$.

\section{Statistics}

The values are expressed as the mean \pm s.d. or mean \pm s.e. and accompanied by the number of observations. Statistical significance was assessed by Student's $t$ test and $P$ values less than 0.05 were considered significant

\section{Results}

Mechanical responses evoked by spasmogenic agents in intact and skinned muscle tissues

Figure 1a shows the mechanical effects that five spasmogenic

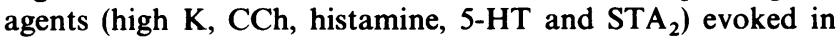
tracheal smooth muscle strips. The amplitude of the $\mathrm{K}$ induced contraction $(128 \mathrm{~mm})$ was much smaller than the CCh-induced contraction $(10 \mu \mathrm{M})$, as previously observed in the rabbit trachea (Fujiwara et al., 1988). Histamine- and 5-HT $(10 \mu \mathrm{M})$-induced contractions were larger than the $\mathrm{K}$ induced contraction but smaller than the CCh-induced contraction. The minimum concentration of $\mathrm{STA}_{2}$ required to evoke a contraction was $1 \mu \mathrm{M}$, and at $10 \mu \mathrm{M}$ the amplitude was slightly enhanced, but the amplitudes were always smaller than those evoked by other agents. In Figure $1 \mathrm{~b}$, the concentration-response relationships are shown for $\mathrm{CCh}$, histamine, $5-\mathrm{HT}$ and $\mathrm{STA}_{2}$. The contraction evoked by $10 \mu \mathrm{M}$ $\mathrm{CCh}$ was normalised as a relative tension of 1.0. The $\mathrm{ED}_{50}$ values for $\mathrm{CCh}$, histamine and 5-HT were $0.8,1.1$ and $0.6 \mu \mathrm{M}$, respectively ( $n=5-7$ preparations). When Ca-free solution containing $0.2 \mathrm{mM}$ EGTA was applied $3 \mathrm{~min}$ before application of the spasmogenic agents, the $\mathrm{K}$-induced contraction

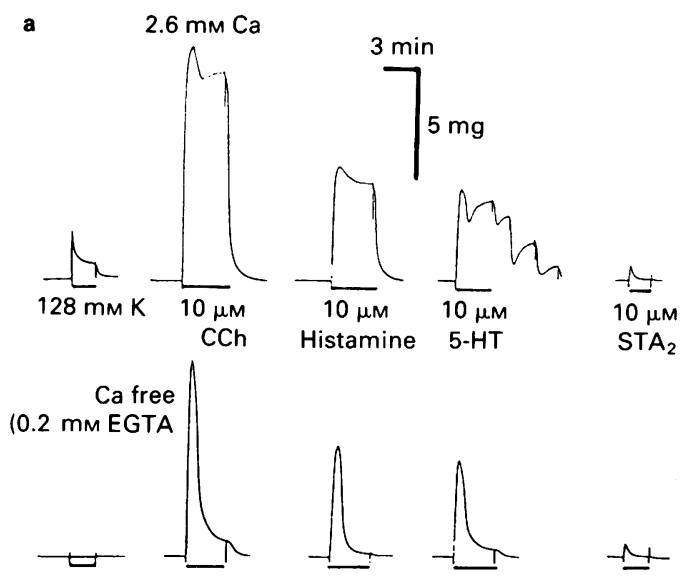

b

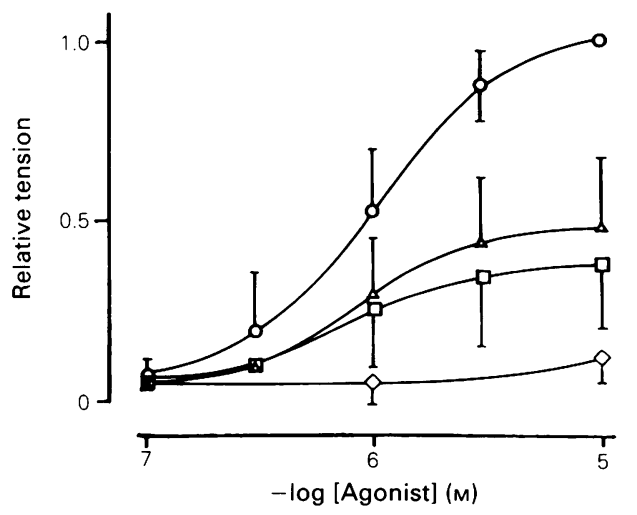

Figure 1 Contractions induced by $128 \mathrm{mM} \mathrm{K}, 10 \mu \mathrm{M}$ carbachol (CCh), histamine, 5-hydroxytryptamine (5-HT) and 9,11-epithio-11,12thromboxane $A_{2}\left(S_{2} A_{2}\right)$ in smooth muscle tissues in Krebs or Ca-free solution containing $0.2 \mathrm{mM}$ EGTA (a) and the concentration-response relationships for the above spasmogenic agents (b). The peak amplitude of CCh-induced contraction $(10 \mu \mathrm{M})$ was normalised as a relative tension of 1.0. Symbols with vertical bars indicate the mean value with s.d., $n=5$. In (b), $(O), \mathrm{CCh},(\triangle)$ histamine, $(\square)$ 5-HT and $(\diamond)$ STA $_{2}$.

and tonic responses of the CCh- histamine- and 5-HT-induced contractions ceased, but the phasic responses evoked by these agents remained almost unchanged. When $0.1 \mu \mathrm{M}$ nifedipine was applied with the spasmogenic agents $(10 \mu \mathrm{M})$, the tonic response was markedly inhibited but the phasic response only slightly inhibited (not shown), as previously observed in the rabbit trachea (Fujiwara et al., 1988).

Figure 2 shows the contraction evoked by $10 \mu \mathrm{M} C \mathrm{Ch}$ in an intact muscle tissue and that evoked by cumulatively applied $\mathrm{Ca}$ at various concentrations to skinned muscle tissue (see Methods). The minimum concentration of $\mathrm{Ca}$ required to evoke a contraction was $0.1 \mu \mathrm{M}$ in relaxing solution and the maximum amplitude was obtained with $10 \mu \mathrm{M} \mathrm{Ca}$. The contraction evoked by $1-3 \mu \mathrm{M}$ Ca was of much the same amplitude as the CCh-induced contraction $(10 \mu \mathrm{M})$. The concentration-response relationship for $\mathrm{Ca}$ observed in skinned muscle tissues (Figure $2 \mathrm{~b}$ ) was almost the same as that observed in the guinea-pig mesenteric artery (Itoh $e t$ al., 1981). Figure $2 \mathrm{c}$ and $\mathrm{d}$ shows, respectively, the effects of $\mathrm{IP}_{3}$ and caffeine on the $\mathrm{Ca}$ store site in skinned smooth muscle tissues. In skinned muscle tissue, $1 \mu \mathrm{M}$ Ca buffered with $4 \mathrm{~mm}$ EGTA-containing relaxing solution was applied to accumulate $\mathrm{Ca}$ in the storage sites, and subsequently the tissue was rinsed with relaxing solution containing $0.1 \mathrm{mM}$ EGTA with $6 \mathrm{~mm}$ inorganic phosphate $\left(P_{i}\right)$ to relax the tissue. After the tissue had relaxed completely, that solution was replaced with $0.1 \mathrm{mM}$ EGTA-containing relaxing solution for $2 \mathrm{~min}$ and either $20 \mu \mathrm{M} \mathrm{IP}_{3}$ or $25 \mathrm{mM}$ caffeine was applied. Used in this 


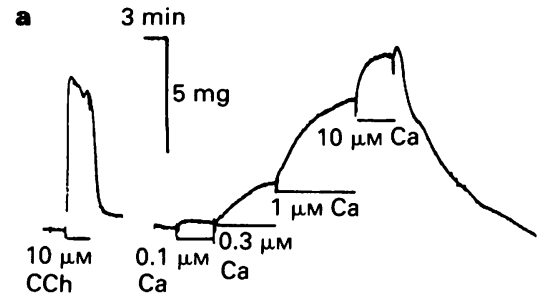

b
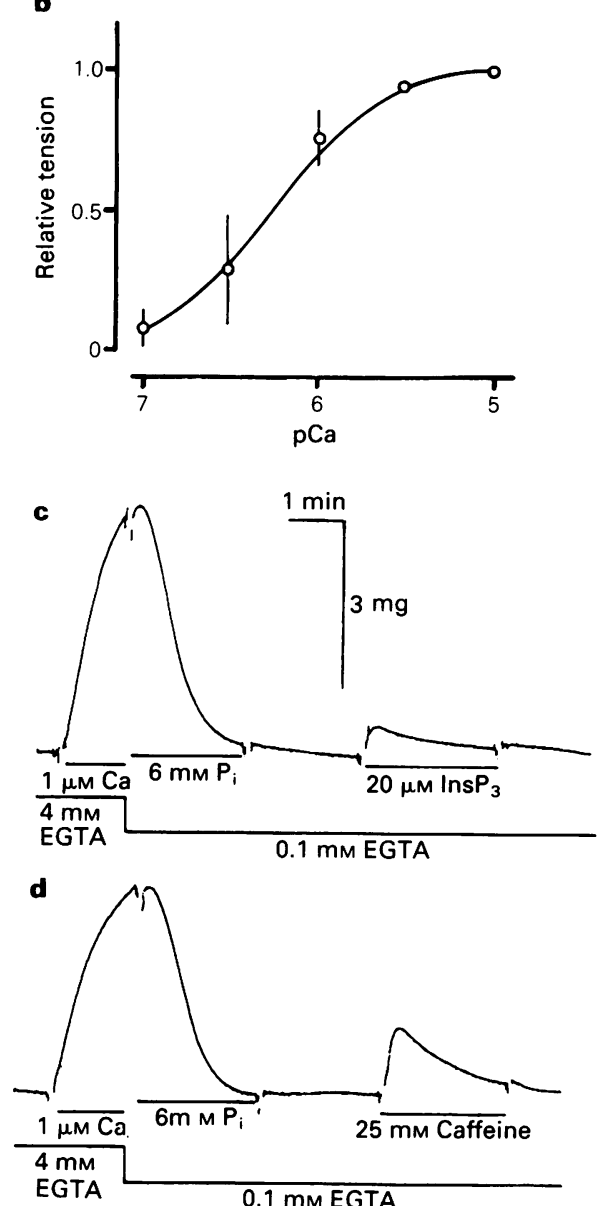

Figure 2 Effects of various concentration of $\mathrm{Ca}$ on skinned muscle tissues prepared by saponin treatment. (a) In intact tissues, $10 \mu \mathrm{M} \mathrm{CCh}$ was applied. After the $\mathrm{CCh}$-induced contraction had been recorded, saponin $40 \mu \mathrm{g} \mathrm{ml}^{-1}$ was applied for $20 \mathrm{~min}$ in relaxing solution in order to prepare skinned muscle. Various concentrations of $\mathrm{Ca}(0.1-$ $10 \mu \mathrm{M})$ were cumulatively applied. (b) The concentration-response relationship for $\mathrm{Ca}$ in skinned muscle tissues. The contraction evoked by $10 \mu \mathrm{M}$ Ca was normalised as $1.0(n=5)$. Symbols with vertical bars indicate mean \pm s.d. $(n=5)$. (c) and (d), effects of $\mathrm{IP}_{3}(\mathrm{c})$ or caffeine (d) on skinned smooth muscle tissues after accumulation of $\mathrm{Ca}$ in the storage site. $P_{i}$ indicates inorganic phosphate added in the relaxing solution. The experimental procedures are described in the text. InsP $_{3}=$ inositol 1,4,5-trisphosphate.

way, both $\mathrm{IP}_{3}$ and caffeine evoked a contraction. (Figure 2c and d).

\section{Relationship between the contraction and} phosphorylation of $M L C_{20}$ evoked by spasmogenic agents

When spasmogenic agents, with the exception of $\mathrm{STA}_{2}$, were applied for over $30 \mathrm{~min}$, a sustained tonic contraction could be recorded (Figure 3a). In Figure 3b, the peak amplitude of the phasic response evoked by $10 \mu \mathrm{M} \mathrm{CCh}$ (measured at about $30 \mathrm{~s}$ after application) was normalised as a relative tension of 1.0. A few minutes after application of $10 \mu \mathrm{M} \mathrm{CCh}$, histamine or 5-HT, the amplitude of contraction reached a steady value,
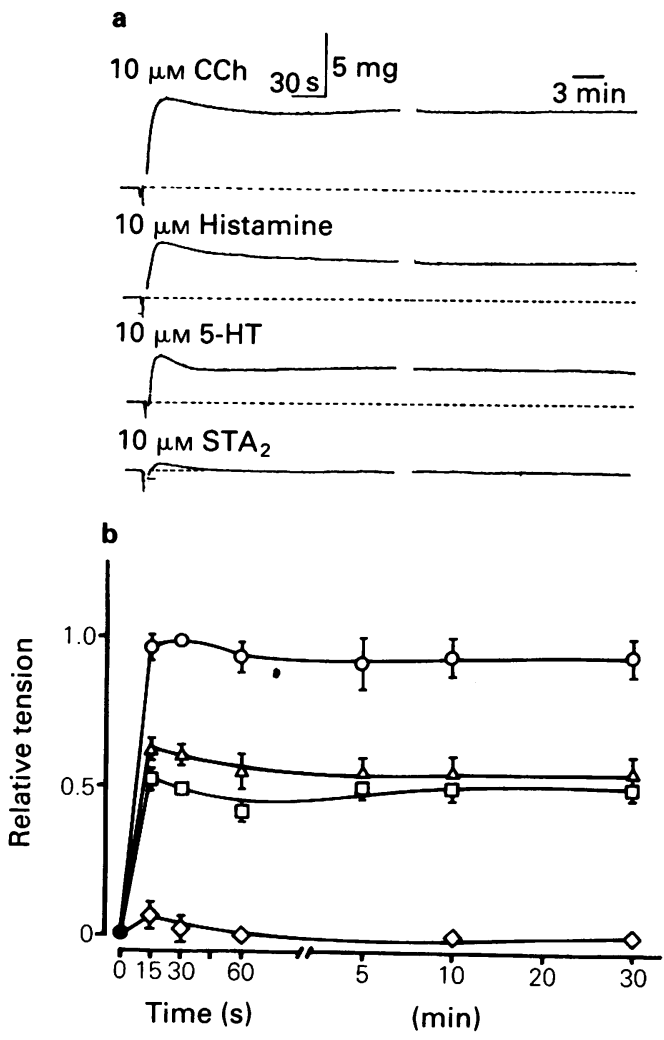

Figure 3 Mechanical responses evoked by $10 \mu \mathrm{M}$ carbachol (CCh) histamine, 5-hydroxytryptamine (5-HT) or 9,11-epithio-11,12-thromboxane $\mathrm{A}_{2}\left(\mathrm{STA}_{2}\right)$ in smooth muscle tissues. (a) Mechanical responses evoked by the 4 different spasmogenic agents. (b) Time courses of mechanical responses evoked by the same agents. The peak amplitude of the CCh $(10 \mu \mathrm{M})$-induced contraction (at $30 \mathrm{~s})$ was normalised as 1.0. Symbols and vertical bars indicate mean and s.d., $n=6$. (O) $\mathrm{CCh}$, $(\Delta)$ histamine, $(\square)$ 5-HT and $(\diamond)$ STA $_{2}$.

which was slightly lower than the peak value, and then remained unchanged for over $30 \mathrm{~min}$.

To investigate the relationship between contraction and phosphorylation of $\mathbf{M L C}_{20}$ under treatment with spasmogenic agents, the phosphorylation was measured by twodimensional gel electrophoresis (see Methods). Phosphorylation of $\mathrm{MLC}_{20}$ induced by CCh, 5-HT and histamine increased in a concentration-dependent manner (Figure $4 a-c)$. The amount of phosphorylation observed in the resting condition was $23.5 \pm 4.6 \%(n=11$, control). The minimum

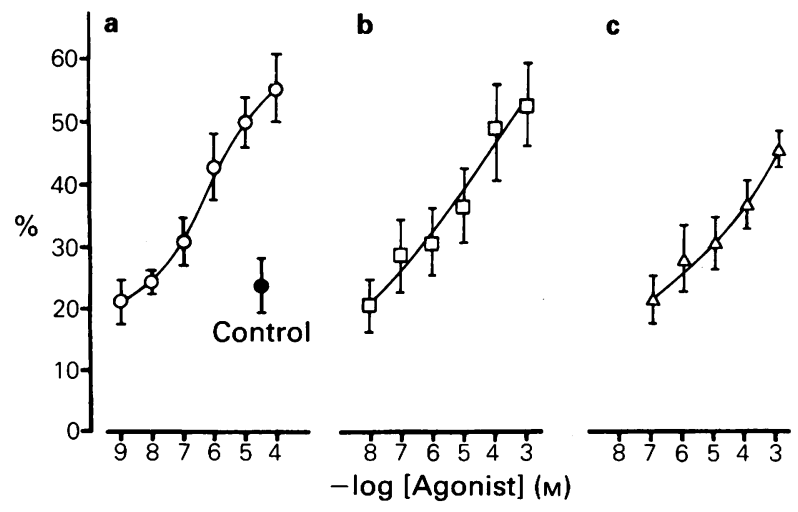

Figure 4 Effects of various concentrations of carbachol $(\mathrm{CCh}, \mathrm{a}), 5$ hydroxytryptamine (5-HT, b) or histamine (c) on phosphorylations of the $20 \mathrm{kD}$ protein of myosin light chain $\left(\mathrm{MLC}_{20}\right)$. The measurement procedure was as described in the Methods. Control; basal phosphorylation level of $\mathrm{MLC}_{20}$ (see text; $n=11$ ). Symbols and vertical bars indicate mean and s.d., $n=5-9$. 
concentration required to phosphorylate $\mathrm{MLC}_{20}$ was lower for CCh $(10 \mathrm{nM})$ than for 5-HT or histamine $(0.1$ and $1 \mu \mathrm{M}$, respectively, $n=5-9$ ). Even with $0.1 \mathrm{mM} \mathrm{CCh}$ or with $1 \mathrm{mM}$ of 5-HT or histamine, phosphorylation did not reach the maximum value possible.

As shown in Figure 5a, when higher concentrations of $\mathrm{CCh}$ (0.1 mM), 5-HT (1 mM) and histamine (1 mM) were applied (i.e. the maximum concentrations of spasmogenic agents used in Figure 4), the peak increase in phosphorylation was observed within $1 \mathrm{~min}$, but $30 \mathrm{~min}$ later, the amount of phosphorylation had fallen slightly.

Figure $5 \mathrm{~b}$ shows the phosphorylation of $\mathrm{MLC}_{20}$ induced by applications of $10 \mu \mathrm{M} \mathrm{CCh}$, histamine, or 5-HT for $30 \mathrm{~min}$ (cf. Figure 3). In Krebs solution, the phosphorylation was $23.5 \pm 4.8 \%(n=11)$ and $1 \mathrm{~min}$ after application of the spasmogenic agents, phosphorylation had increased to $49.3 \pm 4.0$ (CCh), to $30.7 \pm 4.5$ (histamine) or to $36.4 \pm 6.6 \%$ (5-HT) $(n=6)$. In these experiments, attenuation of the phosphorylation of $\mathrm{MLC}_{20}$ in the presence of individual spasmogenic agents occurred very slowly, if at all. It was slight in the case of CCh even after $30 \mathrm{~min}$, and with 5-HT and histamine, the increased phosphorylation remained unchanged $(42.2+4.3 \%$ for $\mathrm{CCh}, 31.6+3.2 \%$ for histamine and $34.7 \pm 3.2 \%$ for 5-HT, $n=5-6$ ). The levels of phosphorylation induced by histamine and 5-HT $(10 \mu \mathrm{M})$ reached almost the same value $(P>0.05)$

\section{Amount of cyclic nucleotides and $I P_{3}$ following application of spasmogenic agents}

Figure 6 shows the amount of $\mathrm{IP}_{3}$ synthesized following the application of various spasmogenic agents against time. Following the application of $10 \mu \mathrm{M} \mathrm{CCh}, 5-\mathrm{HT}$, histamine or STA $A_{2}$, the maximum increase of $\mathrm{IP}_{3}$ occurred after 15-30s, and then rapidly declined to the control level within $3 \mathrm{~min}$.

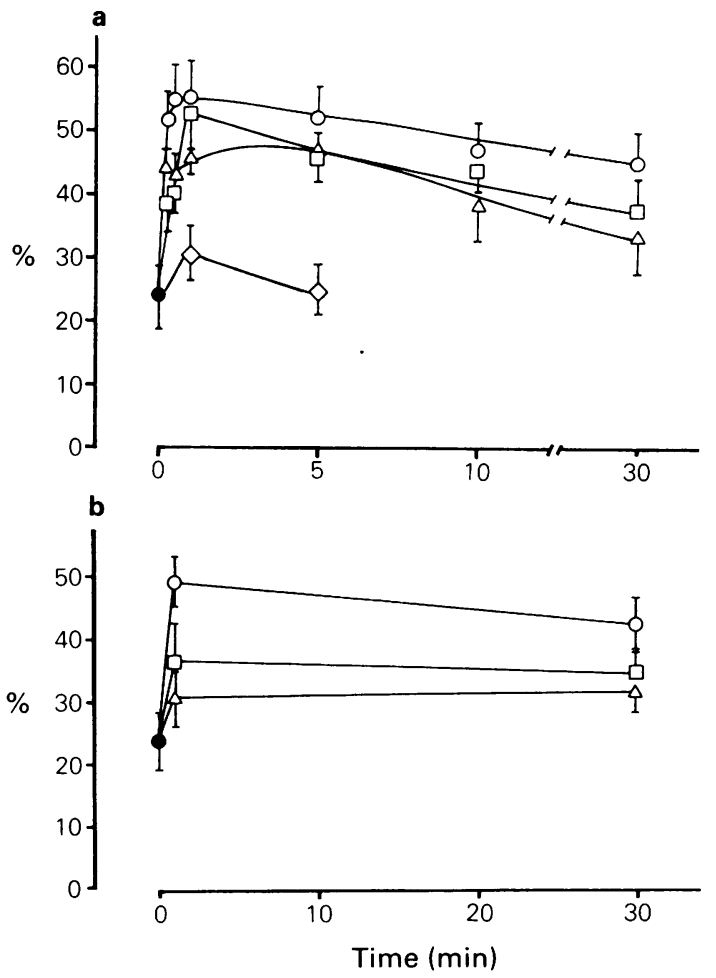

Figure 5 Time course of phosphorylations of $\mathrm{MLC}_{20}$ induced by application of $0.1 \mathrm{mM}$ carbachol (CCh), $1 \mu \mathrm{M}$ 9,11-epithio-11,12-thromboxane $\mathrm{A}_{2}$ (STA $), 1 \mathrm{mM}$ 5-hydroxytryptamine (5-HT) or histamine (a) and $10 \mu \mathrm{M}$ CCh, 5-HT, histamine or STA (b). (O) Control $(23.5 \pm 4.8 \%, n=11)$; (O) CCh, $(\square)$ 5-HT, $(\triangle)$ histamine and $(\diamond)$ STA $_{2}$. Values are expressed as mean and vertical lines show s.d. $(n=5-6)$.
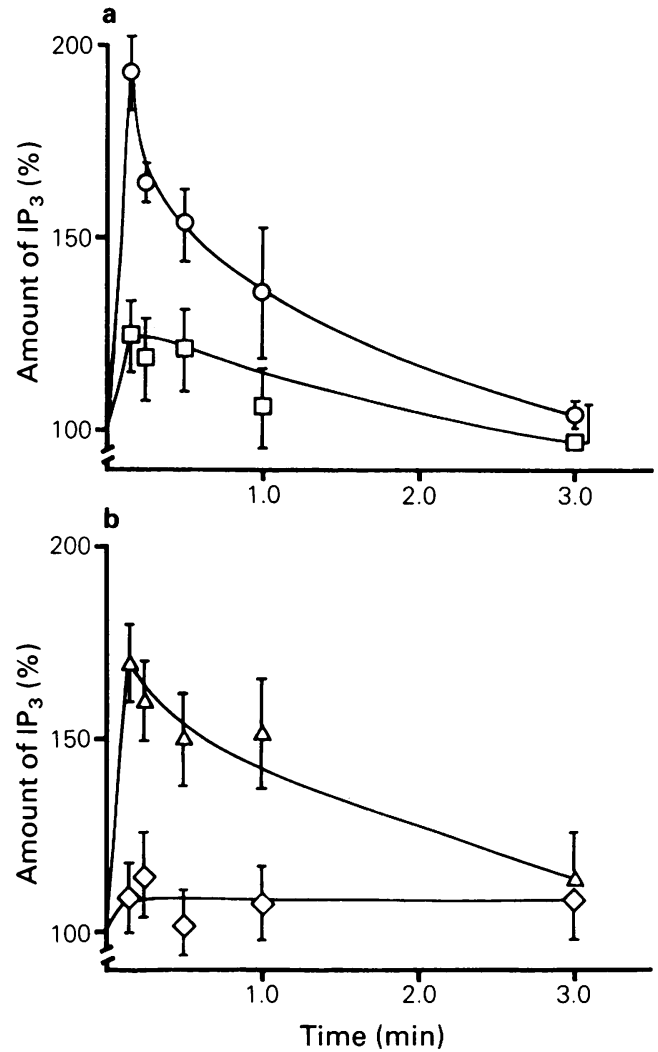

Figure 6 Time courses of synthesis of inositol, 1,4,5-trisphosphate $\left(\mathrm{IP}_{3}\right)$ induced by $10 \mu \mathrm{M}$ carbachol $(\mathrm{O})$ and 5-hydroxytryptamine ( $\square$ ) (a), and histamine $(\Delta)$ and 9,11-epithio-11,12-methano-thromboxane $\mathrm{A}_{2}(\diamond)(\mathrm{b})$. Symbols and vertical bars indicate mean and s.d., $n=4-5$. Concentrations of $\mathrm{IP}_{3}$ measured before application of spasmogenic agents was normalised as $100 \%\left(3.77 \pm 1.66 \mathrm{pmol} \mathrm{mg}^{-1}\right.$ protein, $n=18)$.

The amount of $I_{P_{3}}$ observed in the resting state $\left(3.77 \pm 1.66 \mathrm{pmol} \mathrm{mg}^{-1}\right.$ protein, $\left.n=18\right)$ was normalised as $100 \%$. The maximum amount of $\mathrm{IP}_{3}$ occurring on application of $\mathrm{CCh}(193 \pm 9 \%, n=4)$ was greater than that on application of histamine $(169 \pm 9 \%, n=4)$ or 5 -HT $(125 \pm 10 \%$, $n=5$ ). Following application of $10 \mu \mathrm{M} \mathrm{STA}$, the synthesis of $\mathrm{IP}_{3}$ was small and the difference from control was not statistically significant $(114 \pm 11 \%, n=5, P>0.05)$.

The concentration-response relationships for synthesis of $\mathrm{IP}_{3}$ observed following applications of spasmogenic agents are shown in Figure 7. The amount of $\mathrm{IP}_{3}$ synthesized before the application of agents was normalised as $100 \%$ (as shown in Figure 6). The relative amounts of $\mathrm{IP}_{3}$ synthesized by spasmogenic agents was: $\mathrm{CCh}>$ histamine $>5-\mathrm{HT}$. The $\mathrm{EC}_{50}$ values for synthesis of $\mathrm{IP}_{3}$ for $\mathrm{CCh}$, histamine and 5-HT were $1 \mathrm{nM}$, $1.6 \mathrm{nM}$ and $60 \mathrm{nM}(n=4-6)$, respectively. On application of cimetidine $(100 \mu \mathrm{M}), 5 \mathrm{~min}$ before and during application of $10 \mu \mathrm{M}$ histamine, the increase in $\mathrm{IP}_{3}$ induced by histamine remained unchanged, whereas, after application of mepyramine $(10 \mu \mathrm{M})$ histamine failed to increase $\operatorname{IP}_{3}$ (data are not shown).

The amount of cyclic AMP or cyclic GMP was also measured after application of spasmogenic agents. Isoprenaline, a substance known to produce cyclic AMP, was used for comparison with the spasmogenic agents (Figure 8a). The concentration of cyclic AMP before the application of any of the agents was normalised as a relative value of $100 \%$ $\left(22.4 \pm 2.96 \mathrm{pmol} \mathrm{mg}^{-1}\right.$ protein, $\left.n=25\right)$. Isoprenaline $(10 \mu \mathrm{M})$ consistently increased cyclic AMP and after $3 \mathrm{~min}$, the level had increased to twice control $(198.7 \pm 5.8 \%, n=5)$. However, CCh $(10 \mu \mathrm{M})$ within $15 \mathrm{~s}$ had slightly reduced the amount of cyclic AMP to $78.7 \pm 10.9 \%(n=5 ; P<0.05)$, but 3 min after application the amount of cyclic AMP had recovered to $89.7 \pm 6.9 \%$ of control $(n=5 ; P>0.05)$. 5-HT $(10 \mu \mathrm{M})$ 


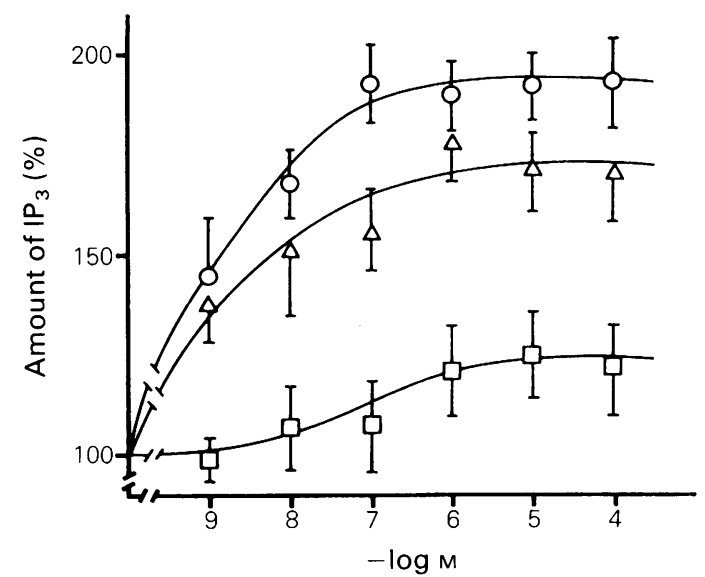

Figure 7 Effects of various concentrations (1 $\mathrm{nm}-0.1 \mathrm{~mm})$ of carbachol $(O)$, 5-hydroxytryptamine $(\square)$ or histamine $(\triangle)$ on synthesis of inositol 1,4,5-trisphosphate $\left(\mathrm{IP}_{3}\right)$. The maximum increase in concentration of $\mathrm{IP}_{3}\left(15-30 \mathrm{~s}\right.$ after application) is plotted. The amount of $\mathrm{IP}_{3}$ measured before application of spasmogenic agents was normalised as $100 \%\left(3.77 \pm 1.66 \mathrm{pmol} \mathrm{mg}^{-1}\right.$ protein, $\left.n=18\right)$. Symbols and vertical bars indicate mean and s.d., $(n=4-6)$.

and $\mathrm{STA}_{2}(10 \mu \mathrm{M})$ had almost no effect on the synthesis of cyclic AMP (Figure 8a).

The effects of the various spasmogenic agents on the synthesis of cyclic GMP were also determined (Figure $8 \mathrm{~b}$ ). The amount of cyclic GMP measured before application of any spasmogenic agent was normalised as $100 \%$ (mean value $0.925 \pm 0.11 \mathrm{pmol} \mathrm{mg}^{-1}$ protein, $\left.n=20\right)$. Histamine $(10 \mu \mathrm{M})$

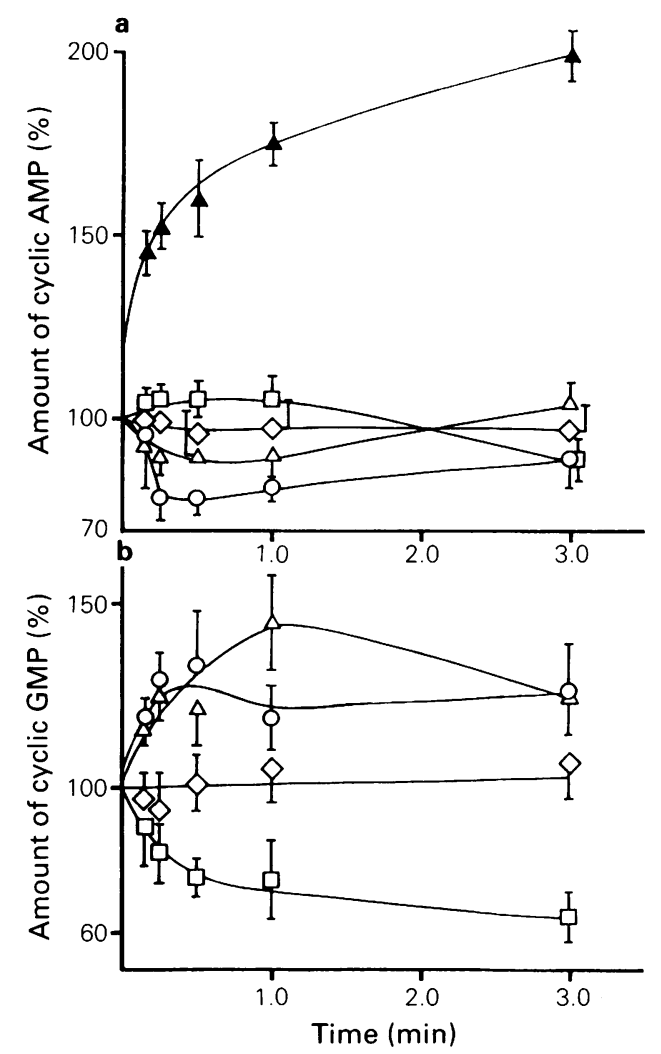

Figure 8 Effects of $10 \mu \mathrm{M}$ carbachol $(\bigcirc)$, 5-hydroxytryptamine $(\square)$ histamine $(\Delta)$ or 9,11-epithio-11,12-methano-thromboxane $A_{2}(\diamond)$ on the synthesis of cyclic AMP (a) and cyclic GMP (b). To obtain a control synthesis of cyclic AMP, isoprenaline $(10 \mu \mathrm{M})$ was applied $(\Lambda$ a). The amounts of cyclic AMP and cyclic GMP measured before application of the drugs were normalised as 1.0 $\left(22.4+2.96 \mathrm{pmol} \mathrm{mg}^{-1}\right.$ protein, $n=25$ and $0.925+0.11 \mathrm{pmol} \mathrm{mg}^{-1}$ protein, $n=20$, respectively). Symbols and vertical bars indicate mean and s.d., $n=5$. consistently increased the amount of cyclic GMP, the maximum value being obtained $1 \mathrm{~min}$ after application $(144.8 \pm 12.8 \%, n=5)$ and after $3 \mathrm{~min}$ it was still $123.9 \%$ of the control $(n=5)$.

This histamine-induced increase in cyclic GMP was marginally inhibited by cimetidine $(100 \mu \mathrm{M}$; reduced to $121.0 \pm 13.2 \%$ after $1 \mathrm{~min}, n=5 ; p>0.05)$ and significantly inhibited by mepyramine $(10 \mu \mathrm{M}$; reduced to $116.0 \pm 4.8 \%$, after $1 \mathrm{~min}, n=5 ; p<0.05$ ).

As shown in Figure $8 \mathrm{~b}, \mathrm{CCh}(10 \mu \mathrm{M})$ also increased cyclic GMP within $30 \mathrm{~s}$, but after 1 min the amount of cyclic GMP had fallen by more than it had with histamine. On the other hand, 5-HT $(10 \mu \mathrm{M})$ reduced the amount of cyclic GMP consistently and $3 \mathrm{~min}$ after its application, the amount was still lower than the control value $(64.7 \pm 4.7 \%, n=5, P<0.01)$. $\mathrm{STA}_{2}(10 \mu \mathrm{M})$ had no effect on the amount of cyclic GMP.

\section{Effects of CCh, histamine, 5-HT and ST $\mathrm{A}_{2}$ on the free concentration of $\mathrm{Ca}$ as measured with fura 2}

The mean basal amount of $\mathrm{Ca}$ was calculated to be $180 \mathrm{~nm}$ $(n=8)$. When CCh $(10 \mu \mathrm{M})$ was applied to the fura 2 loaded strips in Krebs solution, the Ca transient increased from the basal level of $182 \mathrm{nM}$ to $1.42 \mu \mathrm{M}$ within $10 \mathrm{~s}$ (see Methods), then the peak intensity gradually declined to a certain sustained level ( $480 \mathrm{nM}$ after $3 \mathrm{~min}$ ). Figure 9A shows the effects of $10 \mu \mathrm{M}$ $\mathrm{CCh}, 5-\mathrm{HT}$, histamine and STA $\mathrm{S}_{2}$ on the Ca transient (F340 and F380 in Figure 9Aa and the ratio of F340/F380 in Figure 9Ab) compared to the mechanical responses induced by the various spasmogenic agents, Figure 9B shows a summary of the results obtained with the spasmogenic agents on the $\mathrm{Ca}$ transient $(n=4-8)$ at the peak and 2 min after their application. The peak amplitude of the $\mathrm{CCh}$-induced fluorescence

A
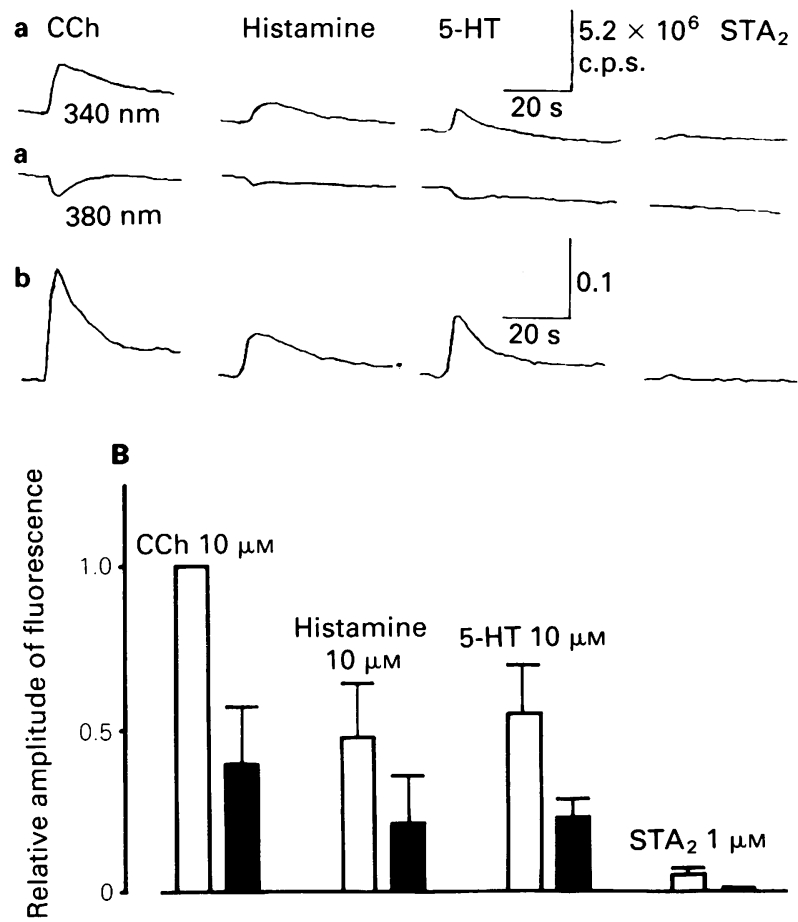

Figure 9 Ca transients measured on application of $10 \mu \mathrm{M}$ carbachol (CCh), histamine, 5-hydroxytryptamine (5-HT) or $10 \mu \mathrm{M}$ 9,11-epithio11,12-methano-thromboxane $\mathrm{A}_{2}\left(\mathrm{STA}_{2}\right.$ ) with fura 2. (Aa and b) Measurements of fluorescence intensities at $F 340$ and $F 380$ and the ratio of these two intensities (F340/F380). (b) Comparison of fluorescence intensities measured in the presences of $10 \mu \mathrm{M} \mathrm{CCh}$, histamine, 5-HT or STA 2 at peak (open columns) and $2 \mathrm{~min}$ after application (solid columns). The peak fluorescence intensity measured on application of $10 \mu \mathrm{M} \mathrm{CCh}$ was normalised as 1.0. Bars indicate s.d., $n=6$. 
intensity (F340/F380) was normalised as a relative value of 1.0. The intensity of fluorescence measured in the presence of 5-HT or histamine was only half that measured in the presence of $\mathrm{CCh}$

\section{Discussion and conclusions}

In the present experiments, the spasmogenic agents used on tracheal smooth muscle tissues were $\mathrm{CCh}$, histamine, 5-HT and STA $\mathrm{A}_{2}$. All the agents produced contraction but to different extents. CCh produced the largest contraction, and 5-HT and histamine both produced a contraction which was half the amplitude of the $\mathrm{CCh}$-induced contraction. STA 2 produced the smallest amplitude of transient contraction. Therefore, the experiments were carried out mainly with $\mathrm{CCh}, 5-\mathrm{HT}$ and histamine.

The amplitude of the CCh-induced contraction $(10 \mu \mathrm{M})$ was equivalent to the contraction evoked by $2 \mu \mathrm{M} \mathrm{Ca}$, as estimated from the concentration-response relationship observed in skinned muscle tissues, and with $1.42 \mu \mathrm{M}$ free $\mathrm{Ca}$ in the cytosol as estimated by fura 2 , and about $50 \%$ of $\mathrm{MLC}_{20}$ was phosphorylated. Initial increases in the concentrations of $\mathrm{Ca}$ (as indicated by fura 2) are probably related to the increase in both the phasic contraction and synthesis of $\mathrm{IP}_{3}$ (about $200 \%$ ). In addition, $\mathrm{CCh}$ inhibited the synthesis of cyclic AMP and slightly increased the synthesis of cyclic GMP. Such concomitant changes in the cyclic nucleotides may partly modify the amplitude of contraction induced by $\mathrm{CCh}$.

The minimum concentrations of the spasmogenic agents required to produce a contraction and the $\mathrm{ED}_{50}$ values for the mechanical responses were much larger than those required to synthesize $I_{P_{3}}$. From the present experiments, we failed to explain these discrepancies. However, it is natural to postulate that some discrepancies may occur between the synthesis of $\mathrm{IP}_{3}$, increased free $\mathrm{Ca}$ and generation of contraction. For example, the minimum concentration of $\mathrm{Ca}$ required to produce a contraction in skinned muscle strips was $100 \mathrm{~nm}$ (Figure 2), but since the intact tissue has a resting tone, much increased concentrations of the cytosolic $\mathrm{Ca}$ (or $\mathrm{IP}_{3}$ ) might be required for the generation of a contraction.

Histamine $(10 \mu \mathrm{M})$ and 5-HT $(10 \mu \mathrm{M})$ produced only about half the amplitude of contraction evoked by $10 \mu \mathrm{M} \mathrm{CCh}$. Histamine increased $\mathrm{IP}_{3}$ to about $170 \%$ of the control, whereas 5-HT increased the amount of $\mathrm{IP}_{3}$ to $125 \%$. When the phosphorylation of $\mathrm{MLC}_{20}$ was compared, 5-HT and histamine produced much the same effect $(30.7 \%$ vs $36.4 \%$ from $23.5 \%$, respectively, $P<0.05$ ). Thus, $\mathrm{Ca}$ released from the sarcoplasmic reticulum by $\mathrm{IP}_{3}$ stimulated by histamine is less completely utilised for the phosphorylations of $\mathrm{MLC}_{20}$ through Ca-calmodulin-myosin light chain kinase- $\mathbf{M L C}_{20}$ processes than is the case with 5-HT. When the effects of synthesis of cyclic AMP or cyclic GMP were compared, the amount of cyclic AMP was not modified by either agent but the amount of cyclic GMP was increased by histamine, yet reduced by 5-HT. A histamine-induced increase in cyclic GMP has been demonstrated in bovine and guinea-pig tracheal smooth muscles (Duncan et al., 1980; Ganellin \& Parsons, 1982; Nakagawa et al., 1986). It is known that cyclic GMP accelerates $\mathrm{Ca}$ extrusion by activation of $\mathrm{Ca}-\mathrm{ATPase}$ at the sarcolemmal membrane (Popescu et al., 1980; Suematsu et al., 1984). This Ca-pump process may not occur through direct phosphorylation of Ca-ATPase (Eggermont et al., 1988) but through an associated phosphorylation of phosphatidylinositol (Vrolix et al., 1988). Furthermore, the amount of free $\mathrm{Ca}$ measured by fura 2 is reduced by application of nitrocompounds, such as nitroglycerin or nicorandil (Kobayashi et al., 1985; Sumimoto et al., 1987). Thus, Ca released by synthesized IP ${ }_{3}$ may be partly pumped out in the extracellular space by cyclic GMP and, as a consequence, the amount of available free $\mathrm{Ca}$ bound to calmodulin may be reduced. Furthermore, cyclic GMP is known to reduce the affinity of the Ca-calmodulin complex for MLCK through phosphorylations of MLCK, and to inhibit the Ca-induced contraction in skinned muscles tissues (Itoh et al., 1985; Nishikawa et al., 1984). However, to clarify whether or not this inhibition of $\mathrm{MLC}_{20}$ by cyclic GMP plays a physiological role, further experiments are required (Kamm \& Stull, 1986; 1987).

Histamine increased both $\mathrm{IP}_{3}$ and cyclic GMP and these actions were inhibited by cimetidine and mepyramine respectively. Thus, $\mathrm{IP}_{3}$ is synthesized through activation of the $\mathrm{H}_{1}$-receptor. Synthesis of $\mathrm{IP}_{3}$ requires activation of the receptor-GTP-activating protein-phospholipase $\mathrm{C}$ complex, but it is not clear whether synthesis of cyclic GMP requires the activation of the receptor-GTP activating proteinguanylate cyclase or direct activation of the agonist-receptor (guanylate cyclase) complex. Significantly, Chinkers et al. (1989) have shown that the receptor of atrial natriuretic peptide (ANP) is guanylate cyclase itself and this protein is a new class of mammalian sarcolemmal receptor which contains an extracellular ligand binding domain. Furthermore, Rapoport (1986) found that cyclic GMP synthesized by $\alpha$-human ANP and nitro-compounds inhibited the synthesis of $\mathrm{IP}_{3}$. On the other hand, Kajikuri \& Kuriyama (1990) demonstrated that $\alpha$-human ANP but not endotheliumderived relaxing factor inhibits the synthesis of $\mathrm{IP}_{3}$ and this action has no causal relation to the synthesized cyclic GMP, since cyclic GMP and dibutyryl cyclic GMP had no effect on the synthesis of $I_{P_{3}}$. It is, therefore, plausible to postulate that metabolic paths for the synthesis of second messengers may also interact with the synthesis of $\mathrm{IP}_{3}$. During the application of 5-HT, cyclic GMP was reduced below the basal level. This response may act to preserve the increased amount of free $\mathrm{Ca}$ in the cytosol and, thus, produce a larger contraction than that expected from the synthesis of $\mathrm{IP}_{3}$. However, the mechanism underlying the reduction in cyclic GMP is not yet clear.

In the present experiments, when $\mathrm{CCh}$, histamine or 5-HT $(10 \mu \mathrm{M})$ were applied the tissue produced a sustained contraction. When $\mathrm{CCh}$ was applied, the $\mathrm{Ca}$ transient measured with fura 2 was reduced to 0.34 times the peak value within $3 \mathrm{~min}$ (mean value of $480 \mathrm{nM}$ ) and the maximum synthesis of $\mathrm{IP}_{3}$ occurred within $30 \mathrm{~s}$ and ceased within $3 \mathrm{~min}$. Much the same effects were observed on application of 5-HT or histamine. Therefore, dissociations occurred on synthesis of $\mathrm{IP}_{3}$ and the free $\mathrm{Ca}$ level during a sustained contraction. These discrepancies, may, in part, be due to increases in $\mathrm{Ca}$ influx during activation of receptors in intact tissues. The receptor-activated $\mathrm{Ca}$ influx may occur during the application of agonists. On the other hand, discrepancies also occurred between phosphorylations of the $\mathrm{MLC}_{20}$ and free Ca during the generation of a sustained contraction, i.e. phosphorylation remained unchanged after application of spasmogenic agents but the free $\mathrm{Ca}$ concentration transiently increased and then declined to a lower level. These responses are unlikely to be explained solely by a latch phenomenon, because the latch phenomenon is defined by a sustained contraction, with a reduction in the free concentration of $\mathrm{Ca}$ nearly to basal level, reduction in the phosphorylation of $\mathrm{MLC}_{20}$ and lowering of the cyclic rate of cross bridges (Gerthoffer \& Murphy, 1983; Chatterjee \& Murphy, 1983; Rembold \& Murphy, 1986; Chatterjee \& Tejada, 1986). Kamm \& Stull $(1986,1987)$ noted that in smooth muscle tissues, the latch phenomenon was not a prerequisite for the production of a sustained contraction. The present experiments failed to explain the discrepancies observed between the sustained contraction, free $\mathrm{Ca}$ and phosphorylation.

In conclusion, $\mathrm{CCh}$ showed a stronger spasmogenic action than 5-HT, histamine or STA 2 . In intact tissues, the actions of the spasmogenic agents, CCh, 5-HT, histamine and STA $\mathrm{A}_{2}$, for generation of the peak amplitude of contraction (phasic) may occur through increases in the phosphorylation of myosin. Increased cytosolic free $\mathrm{Ca}$ induced by synthesis of $\mathrm{IP}_{\mathbf{3}}$ has a causal relation to the peak amplitude and the phosphorylation, but not in a quantitative manner. The increase in the cytosolic $\mathrm{Ca}$ induced by $\mathrm{IP}_{3}$ may be negatively or positively controlled by other second messengers. However, the 
sustained contractions evoked by the spasmogenic agents cannot be explained by the interactions of the second messengers themselves or their metabolic paths. Thromboxane $A_{2}$ may play a minor role as a spasmogenic agent.

\section{References}

BEAVEN, M.A. (1978). Histamine its Role in Physiological and Pathological Process. Basel: Karger AG.

CHAND, N. \& EYRE, P. (1975). Classification and biological distribution of histamine receptor sub-types. Agent. Actions, 5, 277-295.

CHATTERJEE, M. \& MURPHY, R.A. (1983). Calcium-dependent stress maintenance without myosin phosphorylation in skinned smooth muscle. Science, 221, $464-446$.

CHATTERJEe, M. \& TEJADA, M. (1986). Phorbol ester-induced contraction in chemically skinned vascular smooth muscle. Am. J. Physiol., 251, C356-361.

CHINKERS, M., GARBERS, D.L., CHANG, M., LOWE, D.G., CHIN, H GOEDDEL, D.V. \& SCHULTZ, S. (1989). A membrane form of guanylate cyclase is atrial natriuretic peptide receptor. Nature, $\mathbf{3 3 8}$, 78-83.

DUNCAN, P.G., BRINK, C., ADOLPHSON, R.L. \& DOUGLAS, J.S. (1980) Cyclic nucleotides and contraction/relaxation in airway muscle: $\mathrm{H}_{1}$ and $\mathrm{H}_{2}$ agonists and antagonists. J. Pharmacol. Exp. Ther., 215, 434-442.

DRISKA, S.P., AKSOY, M.O. \& MURPHY, R.A. (1981). Myosin light chain phosphorylation associated with contraction in arteria smooth muscle. Am. J. Physiol., 240, C222-C233.

EGGERMONT, J.A., VROLIX, M., RAEYMAEKERS, L., WUYTACK, F. \& CASTEELS, R. (1988). $\mathrm{Ca}^{2+}$-transport ATPases of vascular smooth muscle. Circ. Res., 62, 266-278.

FELBEL, J., TROCKUR, B., ECKER, T., LANDGRAF, W. \& HOFFMANN F. (1988). Regulation of cytosolic calcium by cAMP and cGMP in freshly isolated smooth muscle cells from bovine trachea. J. Biol. Chem., 263, 16764-16771.

FUJIWARA, T., ITOH, T., KUBOTA, Y. \& KURIYAMA, H. (1989). Effects of guanosine nucleotides on skinned muscle tissue of the rabbit mesenteric artery. J. Physiol., 408, 535-547.

FUJIWARA, T., ITOH, T. \& KURIYAMA, H. (1988). Regional differences in the mechanical properties of rabbit airway smooth muscle. $\mathrm{Br}$. J. Pharmacol., 94, 389-396.

GANELLIN, C.R. \& PARSONS, N.E. (1982). Pharmacology of Histamine Receptors. Bristol: Wright, P.G.S.

GERTHOFFER, W.T. \& MURPHY, R.A. (1983). Myosin phosphorylation and regulation of cross-bridge cycle in tracheal smooth muscle. Am. J. Physiol., 244, C182-C187.

GRYNKIEWICZ, G., POENIE, M. \& TSIEN, R.Y. (1985). A new generation of $\mathrm{Ca}^{2+}$ indicator with greatly improved fluorescence properties. J. Biol. Chem., 260, 3440-3450.

HASHIMOTO, T., HIRATA, M. \& ITO, Y. (1985). A role for inositol 1,4,5trisphosphate in the initiation of agonist-induced contractions of dog tracheal smooth muscle. Br. J. Pharmacol., 86, 191-199.

HIMPENS, B. \& SOMLYO, A.P. (1988). Free-calcium and force transients during depolarization and pharmacomechanical coupling in guinea-pig smooth muscle. J. Physiol., 395, 507-530.

ITO, Y. \& TAJIMA, K. (1982). Dual effects of cathecolamines on the preand post-junctional membranes in the dog trachea. Br. J. Pharmacol., 75, 433-440.

ITOH, T., KANMURA, Y., KURIYAMA, H. \& SASAGURI, T. (1985) Nitroglycerine- and isoprenaline-induced vasodilatation: assessment of cyclic nucleotides. Br. J. Pharmacol., 84, 393-406.

ITOH, T., KANMURA, Y., KURIYAMA, H. \& SUMIMOTO, K. (1986). A phorbol ester has dual actions of the mechanical responses in the rabbit mesenteric and porcine coronary arteries. J. Physiol., 375, $515-534$.

ITOH, T., KURIYAMA, H. \& SUZUKI, H. (1981). Excitation-contraction coupling in smooth muscle cells of the guinea-pig mesenteric artery. J. Physiol., 321, 513-535.

KAJIKURI, J. \& KURIYAMA, H. (1990). Inhibitory action of $\alpha$-human natriuretic peptide on noradrenaline-induced synthesis of myoinositol 1,4,5-trisphosphate in the smooth muscle cells of rabbit aorta. Br. J. Pharmacol., (in press).

KAMM, K.E. \& STULL, J.T. (1986). Activation of smooth muscle con-
We would like to thank Prof. H. Kuriyama for his continuous encouragement and to Dr J. Marshall for reading of the manuscript. This research was supported by Grant-in-aid for Scientific Research on Priority Areas (H. Kuriyama).

traction: relaxation between myosin phosphorylation and stiffness Science, 232, 80-82.

KAMM, K.E. \& STULL, J.T. (1987). Airway smooth muscle and disease workshop: contractile mechanisms. Am. Rev. Respir. Dis., 136, S12-S14.

KIRKPATRICK, C.T. (1975). Excitation and contraction in bovine tracheal smooth muscle. J. Physiol., 244, 263-281.

KOBAYASHI, S., KANAIDE, H. \& NAKAMURA, M. (1985). Cytosolicfree calcium transients in cultured vascular smooth muscle cells: Microfluorescence measurements. Science, 229, 553-556.

KOTLIKOFF, M.I. MURRAY, R.K \& REYNOLDS, E.E. (1987) Histamine-induced calcium release and phorbol antagonism in cultured airway smooth muscle cells. Am. J. Physiol., 253, C561C566.

LOWRY, O.H., ROSEBROUGH, A.L., FARR, A.L. \& RANDALL, R.J. (1951). Protein measurement with the Folin phenol reagent. $J$. Biol. Chem., 193, 265-275.

LUCKHOFF, A. (1986). Measuring cytosolic free calcium concentration in endothelial cells with indo-1: the pitfall of using the ratio of two fluorescence intensities recorded at different wavelengths. Cell Calcium, 7, 233-248.

NAKAGAWA, H., OKA, M., KIMURA, A. \& OHUCHI, T. (1986). Effect of age on the formation of cyclic nucleotides in guinea-pig tracheal smooth muscle in response to pharmacological agents. Eur. J. Pharmacol., 125, 211-216.

NISHIKAWA, M., DE LANEROLLE, P., LINCOLN, T.M. \& ADELSTEIN, R.S. (1984). Phosphorylation of mammalian myosin light chain kinases by the catalytic subunit of cyclic AMP-dependent protein kinase and by cyclic GMP-dependent protein kinase. J. Biol. Chem., 259, 8429-8436.

O'FARRELL, P.H. (1975). High resolution two-dimensional electrophoresis of proteins. J. Biol. Chem., 250, 4007-4021.

POPESCU, L.M, BRUIJN, W.C, ZELAK, U, \& IONESCU, N. (1980). Intracellular distribution of calcium in smooth muscle: facts and artifacts. A correlation of cytochemical, biochemical and $x$-ray microanalytical findings. Morphol. Embryol., 26, 251-258.

RAPOPORT, R.M. (1986). Cyclic guanosine monophosphate inhibition of contraction may be mediated through inhibition of phosphatidyl inositol hydrolysis in rat aorta. Circ. Res., 58, 407-410.

REMBOLD, C.M. \& MURPHY, R.A. (1986). Myoplasmic calcium, myosin phosphorylation, and regulation of the cross bridge cycle in swine arterial smooth muscle. Circ. Res., 58, 803-815.

SATO, K., OZAKI, H. \& KARAKI, H. (1988). Multiple effects of caffeine on contraction and cytosolic free $\mathrm{Ca}^{2+}$ levels in vascular smooth muscle of rat aorta. Naunyn-Schmiedebergs Arch. Pharmacol., 338, 443-448.

SUEMATSU, E., HIRATA, M. \& KURIYAMA, H. (1984). Effects of cAMP- and cGMP-dependent protein kinases, and calmodulin on $\mathrm{Ca}^{2+}$ uptake by highly purified sarcolemmal vesicles of vascular smooth muscle. Biochim. Biophys. Acta, 773, 83-90.

SUMIMOTO, K., DOMAE, M., YAMANAKA, K., HASHIMOTO, T., KITAMURA, K. \& KURIYAMA, H. (1987). Actions of nicorandil on vascular smooth muscles. J. Cardiovasc. Pharmacol., 10, S66-S75.

SUMIMOTO, K. \& KURIYAMA, H. (1986). Mobilization of free $\mathrm{Ca}^{2+}$ measured during contraction-relaxation cycles in smooth muscle cells of the porcine coronary artery using quin-2. Pflügers Arch., 406, 173-180.

TSIEN, R.Y, RINK, T.J. \& POENIE, M. (1985). Measurement of cytosolic free calcium in individual small cells using fluorescence microscopy with dual excitation wavelengths. Cell Calcium, 6, 145-157.

VROLIX, M., RAEYMAEKERS, L., WUYTACK, F., HOFFMANN, F. \& CASTEELS, R. (1988). Cyclic GMP-dependent protein kinase stimulates the plasmalemmal $\mathrm{Ca}^{2+}$ pump of smooth muscle via phosphorylation of phosphatidyl inositol. Biochem. J., 255, 855863.

Received October 17, 1989 Revised January 8, 1990 Accepted January 15, 1990 